\title{
RENEWABLE RESOURSE INTEGRATION IN BIODEGRADABLE COMPOSITES
}

\author{
M.Manins, S.Kukle, G.Strazds, A.Bernava \\ Riga Technical University, Department of Design and Textile Products Technology \\ Azenes St14/24, Riga, LV 1048, Latvia \\ Ph.: +(371 ) 67089816, fax: +(371) 67089160, e-mail: skukle@latnet.lv
}

\begin{abstract}
For a variety of applications it is desirable to produce textile materials with specially designed properties. Reinforcing $2 D$ and $3 D$ woven structures for fibers reinforced polymer composites were developed from renewable natural fibers and tested in this research work. Results and discussion are presented in the paper.
\end{abstract}

Keywords: woven fabrics, reinforcement structures, fibers reinforced polymer composites, mechanical properties.

\section{Introduction}

Textile materials as a components of laminated composites were used from 1960 [1]. Unfortunately high costs as a result of high share of manual labour in production and low resistance to loads in the third direction was the reason to investigate other solutions. 3D textiles were developed and first time as composite reinforcement were applied at 1970 [2]. In the course of time rapid development of applications took place and nowadays it is hard to imagine economic branch without exploitation of fibres reinforced polymer composites FRP [2]. Fabric reinforcements are used for improving FRP bent and stroke resistance. The other advantages of FRP are comparative low density and cost effectiveness, as well plasticity of textiles [3, 4]. For FRP production carbon, aramide and glass high modulus fibres are mainly applied as physical and mechanical properties of them are high and close to corresponding steel properties but density are less (Table 1). As disadvantages of mentioned fibres could be mentioned comparative high costs, low recyclability. For this reason where technical parameters allow less expensive, recyclable basalt or natural bast fibres are used [2].

Natural fibres are renewable, environmental friendly sources of raw materials with a low density; disadvantages of natural fibres are lower modules (Table 1), uneven fibres quality and low heat resistance. Local fibres resources are preferable - in Latvia these are flax and hemp fibres.

Table 1.

Main physical and mechanical properties of fibres for technical usage

\begin{tabular}{|c|c|c|c|c|c|c|c|}
\hline & $\begin{array}{l}\text { Basalt } \\
\text { fibres }\end{array}$ & $\begin{array}{c}\mathbf{E}-\text { glass } \\
\text { fibres }\end{array}$ & $\begin{array}{c}S \text { - glass } \\
\text { fibres }\end{array}$ & $\begin{array}{c}\text { Carbon } \\
\text { fibres }\end{array}$ & $\begin{array}{c}\text { Aramid } \\
\text { fibres }\end{array}$ & $\begin{array}{c}\text { Flax } \\
\text { fibres }\end{array}$ & $\begin{array}{c}\text { Jute } \\
\text { fibres }\end{array}$ \\
\hline $\begin{array}{l}\text { Density } \\
\left(\mathrm{g} / \mathrm{cm}^{3}\right)\end{array}$ & $\begin{array}{c}2,63- \\
2,8\end{array}$ & $\begin{array}{c}2,54- \\
2,57\end{array}$ & 2,54 & 1,78 & 1,45 & 1,4 & 1,46 \\
\hline $\begin{array}{l}\text { Tensile } \\
\text { strength } \\
\text { (Mpa) }\end{array}$ & $\begin{array}{c}4100- \\
4840\end{array}$ & $\begin{array}{c}3100- \\
3800\end{array}$ & $\begin{array}{c}4020- \\
4650\end{array}$ & $\begin{array}{c}3500- \\
6000\end{array}$ & $\begin{array}{c}2900- \\
3400\end{array}$ & $800-1500$ & $400-800$ \\
\hline $\begin{array}{l}\text { Modulus } \\
\text { (Gpa) }\end{array}$ & $\begin{array}{c}93,1- \\
110 \\
\end{array}$ & $72,5-76$ & $83-97$ & $\begin{array}{c}230- \\
600 \\
\end{array}$ & $70-140$ & $60-80$ & $10-30$ \\
\hline $\begin{array}{l}\text { Elongation } \\
(\%)\end{array}$ & 3,1 & 4,7 & 5,3 & $1,5-2$ & $2,8-3,6$ & $1,2-1,6$ & 1,8 \\
\hline $\begin{array}{l}\text { Filament } \\
\text { diameter } \\
(\mathbf{m u})\end{array}$ & $6-21$ & $6-21$ & $6-21$ & $5-15$ & $5-15$ & $9,2-17,7$ & $2-15$ \\
\hline
\end{tabular}


FRP mechanical properties are depended on mechanical properties of fibers and matrix, share of fibers and structure of reinforcing material, fibers/fabric adhesion to matrix, processing parameters.

Reinforcing textile structures in form of $2 \mathrm{D}$ or $3 \mathrm{D}$ fabrics could be produced by weaving, knitting, braiding, sewing, nonwoven or laminating technology. Weaving technology allows produced fabrics for composites starting from plain weaves (2D fabrics) till intricate composite 3D structures with interwoven and straight threads (Fig. 1).
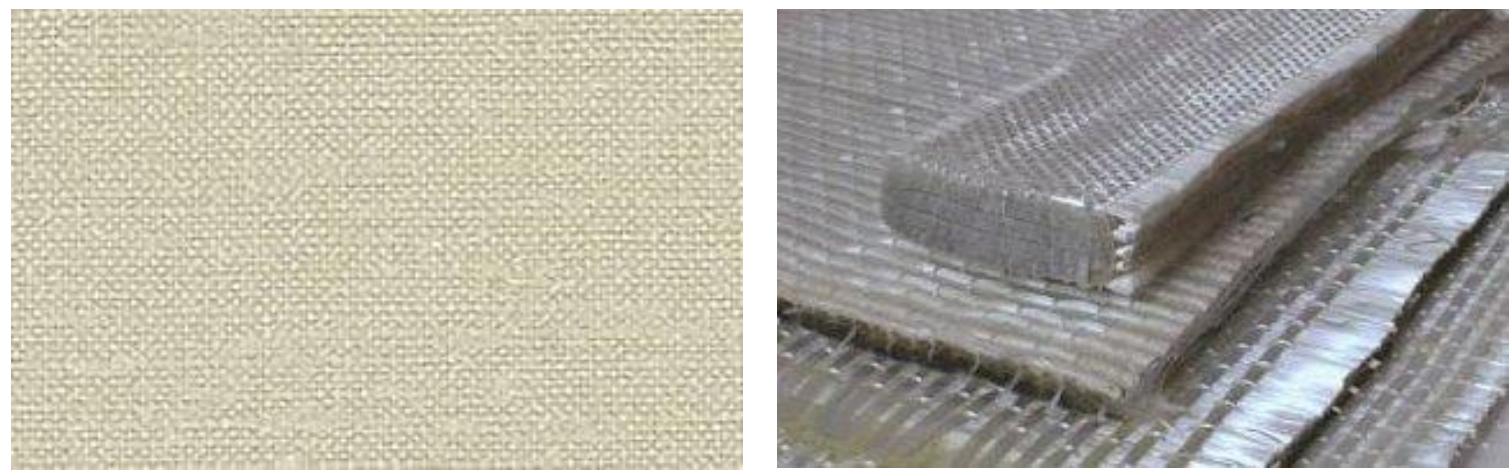

Fig. 1. Composites reinforcing fabric weaves:

plane weave (left), multilayer overlaid weave (right)

2D woven structures are executed in plain, panama, twill, satin, overlaid weaves depending on features of further application and processing. In FRP production processes $2 \mathrm{D}$ fabrics are spread out forming multi layer layouts filled with matrix resins. Impact on costs of manual labour in this technology is still high as a result FRP of this kind are quite expensive. Development of 3D reinforcing structures partially solves problem allowing exclude manual labour.

\section{Materials and methods}

Table 2.

Threads and weaves used in fabric samples processing

\begin{tabular}{|c|c|c|c|c|c|c|c|}
\hline \multirow[b]{2}{*}{$\begin{array}{l}\text { Thread type, } \\
\text { fabric thickness }\end{array}$} & \multicolumn{3}{|c|}{ Flax } & \multicolumn{3}{|c|}{ Jute } & \multirow[b]{2}{*}{$\begin{array}{l}\text { Jute/basalt } \\
\text { Multi- } \\
\text { layer } \\
\text { overlaid } \\
\text { weave } 3 / 3 \\
\end{array}$} \\
\hline & $\begin{array}{l}\text { 2-layer } \\
\text { plain } \\
\text { weave }\end{array}$ & $\begin{array}{l}2 \text { to } 3 \text { - } \\
\text { layer } \\
\text { overlaid } \\
\text { weave } \\
\end{array}$ & $\begin{array}{l}\text { Multi- } \\
\text { layer } \\
\text { overlaid } \\
\text { weave } \\
2 / 2 \\
\end{array}$ & $\begin{array}{l}2- \\
\text { layer } \\
\text { plain } \\
\text { weave }\end{array}$ & $\begin{array}{l}2 \text { to } 3 \text { - } \\
\text { layer } \\
\text { overlaid } \\
\text { weave }\end{array}$ & $\begin{array}{l}\text { Multi- } \\
\text { layer } \\
\text { overla } \\
\text { id } \\
\text { weave } \\
\end{array}$ & \\
\hline Flax, warp 582/2 tex & $\mathrm{x}$ & $\mathrm{x}$ & & & & & \\
\hline Flax, warp $68 / 2$ tex & $\mathrm{x}$ & $\mathrm{x}$ & & $\mathrm{x}$ & $\mathrm{x}$ & $\mathrm{x}$ & $\mathrm{x}$ \\
\hline Jute, warp $482 / 2$ tex & & & & $\mathrm{x}$ & $\mathrm{x}$ & $\mathrm{X}$ & $\mathrm{X}$ \\
\hline $\begin{array}{l}\text { Basalt, warp } 68 / 2 * 2 \\
\text { tex }\end{array}$ & & & & & & & $\mathrm{x}$ \\
\hline Flax, weft 382 tex & $\mathrm{x}$ & $\mathrm{x}$ & $\mathrm{x}$ & & & & \\
\hline Jute, weft $482 / 2$ tex & & & & $\mathrm{X}$ & $\mathrm{x}$ & $\mathrm{X}$ & $\mathrm{x}$ \\
\hline $\begin{array}{l}\text { Basalt, weft } 68 / 2 * 2 \\
\text { tex }\end{array}$ & & & & & & & $\mathrm{x}$ \\
\hline Fabric thickness, mm & 3,84 & 3,84 & 3,85 & 5,35 & 5,32 & 5,33 & 5,35 \\
\hline
\end{tabular}

Reinforcing 2D and 3D woven structures were developed corresponding to experiment plan (Table 2) and tested to investigate influence of warp and weft yarns combinations with weaves on fabric physical and mechanical properties. 


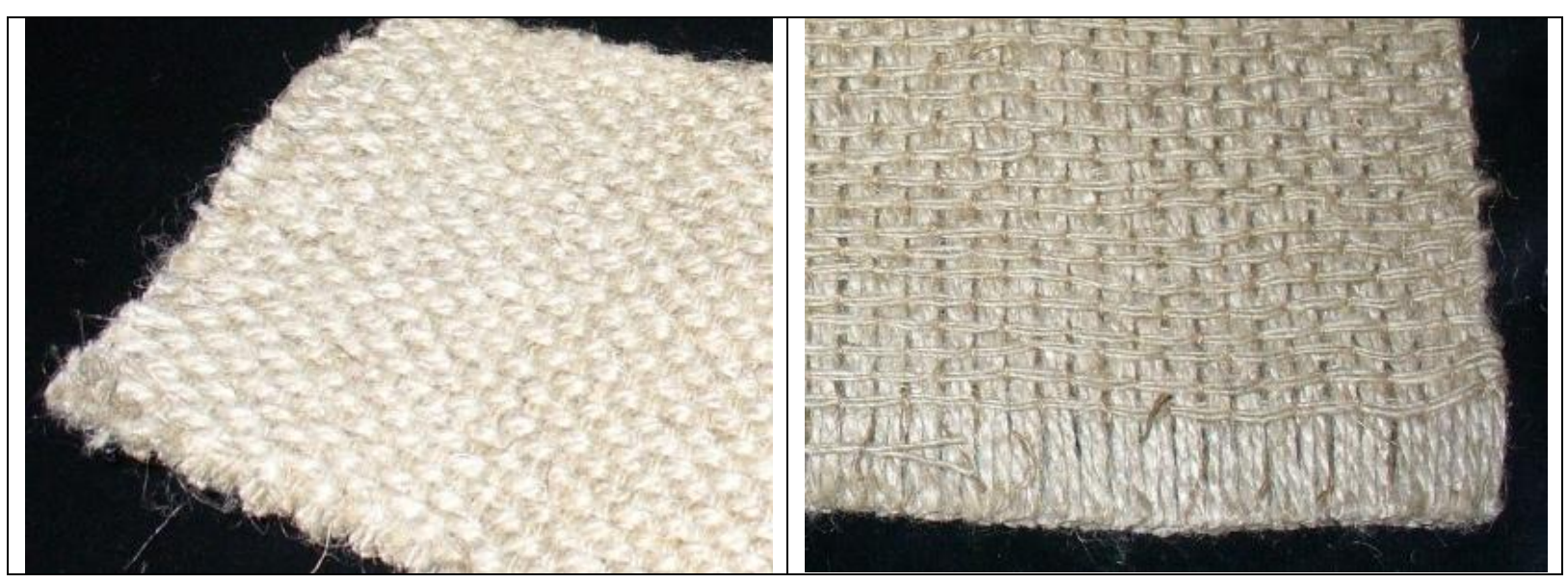

Fig. 2. Samples of woven reinforcement structures

Two layer interwoven plain weave fabric (left), multi layer overlaid weave fabric (right)

7 different fabric structures in different weaves from natural threads are worked out and realized on hand loom (Table 2, Fig. 1 and Fig. 2). For the last structure natural jute threads are combined with the basalt threads (Table 2).

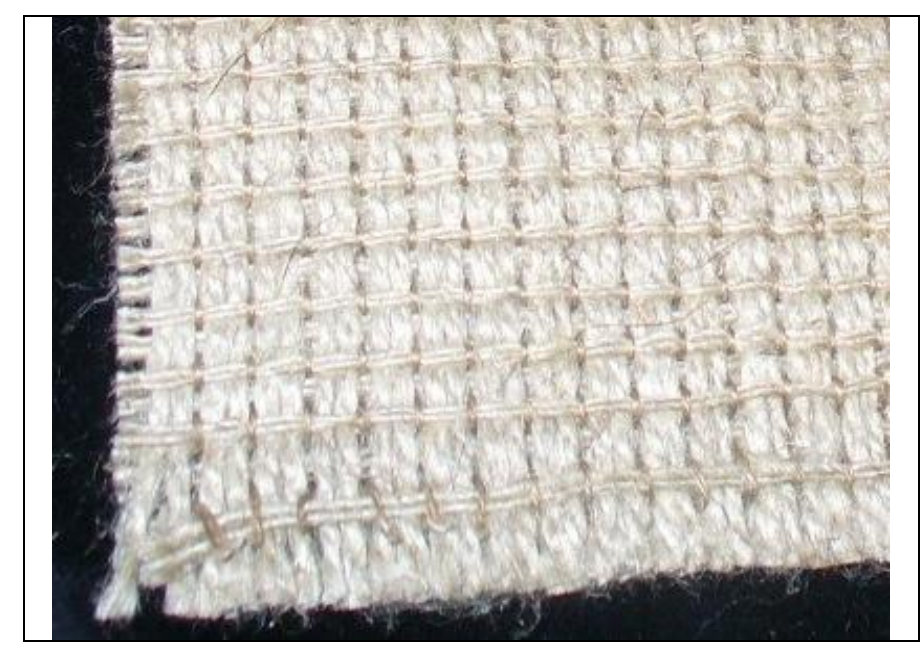

Fig.3. Sample of the woven reinforcement structure. Flax multi-layer overlaid weave $2 / 2$

For testing five $25 \mathrm{~mm}$ wide fabric samples were cut out and mechanical properties are tested on Instron tester in warp and weft directions with the distance between clamps $100 \mathrm{~mm}$, testing velocity $10 \mathrm{~mm} / \mathrm{min}$. Results are shown in Table 3 .

\section{Results and discussion}

Range of samples average surface density values are cover densities from 1210 to $2028 \mathrm{~g} / \mathrm{m}^{2}$, choices possibilities depending of final usage. From Table 3 and graphs in Fig. 5 and Fig. 6 are seen that the largest values of tensile stress and modules show samples with a jute/basalt multi-layer overlaid weave $3 / 3$ tested in the weft direction $(26,92 \mathrm{MPa}$ and $0,81 \mathrm{GPa}$ respetively), tensile stress for the same samples in warp direction is 1,7 times lower, module 1,93 times lower. Only a little lower values (26,19 Mpa) show samples from jute threads with 2 to 3-layer overlaid weave in weft direction that is 2,12 times more then in warp direction, module in weft direction exceed module in warp direction 2,57 times. For all three flax fabric samples tensile stress values in warp direction are slightly higher than in weft direction. 
Table 3.

Physical and mechanical properties of woven fabrics under inspection

\begin{tabular}{|c|c|c|c|c|c|c|}
\hline & $\begin{array}{r}\text { Surface } \\
\text { density } \\
(\mathrm{g} / \mathrm{m} 2)\end{array}$ & $\begin{array}{c}\text { Thread } \\
\text { direction }\end{array}$ & $\begin{array}{c}\text { Tensile } \\
\text { strenght, } \\
\mathbf{N}\end{array}$ & $\begin{array}{l}\text { Tensile } \\
\text { stress, } \\
\text { MPa }\end{array}$ & $\begin{array}{c}\text { Extension, } \\
\text { mm }\end{array}$ & $\begin{array}{c}\text { Modulus } \\
\text { Gpa }\end{array}$ \\
\hline \multirow[t]{2}{*}{ 1. Flax 2-layer plain weave } & \multirow[t]{2}{*}{1353} & Warp & 1793 & 18,63 & 10,4 & 0,18 \\
\hline & & Weft & 1118 & 11,61 & 6,8 & 0,17 \\
\hline \multirow{2}{*}{$\begin{array}{l}\text { 2. Fax } 2 \text { to } 3 \text {-layer overlad } \\
\text { weave }\end{array}$} & \multirow[t]{2}{*}{1866} & Warp & 1606 & 16,73 & 5,5 & 0,31 \\
\hline & & Weft & 1463 & 15,24 & 5,8 & 0,26 \\
\hline \multirow{2}{*}{$\begin{array}{l}\text { 3. Flax multi-layer overlaid } \\
\text { weave } 2 / 2\end{array}$} & \multirow[t]{2}{*}{1318} & Warp & 1865 & 19,43 & 5 & 0,39 \\
\hline & & Weft & 1376 & 14,33 & 4,4 & 0,32 \\
\hline \multirow[t]{2}{*}{ 4. Jute 2-layer plain weave } & \multirow[t]{2}{*}{1210} & Warp & 1284 & 11,81 & 15,8 & 0,08 \\
\hline & & Weft & 1388 & 12,76 & 4,5 & 0,28 \\
\hline \multirow{2}{*}{$\begin{array}{l}\text { 5. Jute } 2 \text { to } 3 \text {-layer overlaid } \\
\text { weave }\end{array}$} & \multirow[t]{2}{*}{2028} & Warp & 1639 & 12,33 & 4,4 & 0,28 \\
\hline & & Weft & 3483 & 26,19 & 3,6 & 0,72 \\
\hline \multirow{2}{*}{$\begin{array}{l}\text { 6. Jute multi-layer overlaid } \\
\text { weave }\end{array}$} & \multirow[t]{2}{*}{1755} & Warp & 1721 & 12,87 & 4,2 & 0,31 \\
\hline & & Weft & 2487 & 18,6 & 3,4 & 0,55 \\
\hline \multirow{2}{*}{$\begin{array}{l}\text { 7. Jute/basalt multi-layer } \\
\text { overlaid weave } 3 / 3\end{array}$} & \multirow[t]{2}{*}{1960} & Warp & 2115 & 15,81 & 3,8 & 0,42 \\
\hline & & Weft & 3600 & 26,92 & 3,3 & 0,81 \\
\hline
\end{tabular}

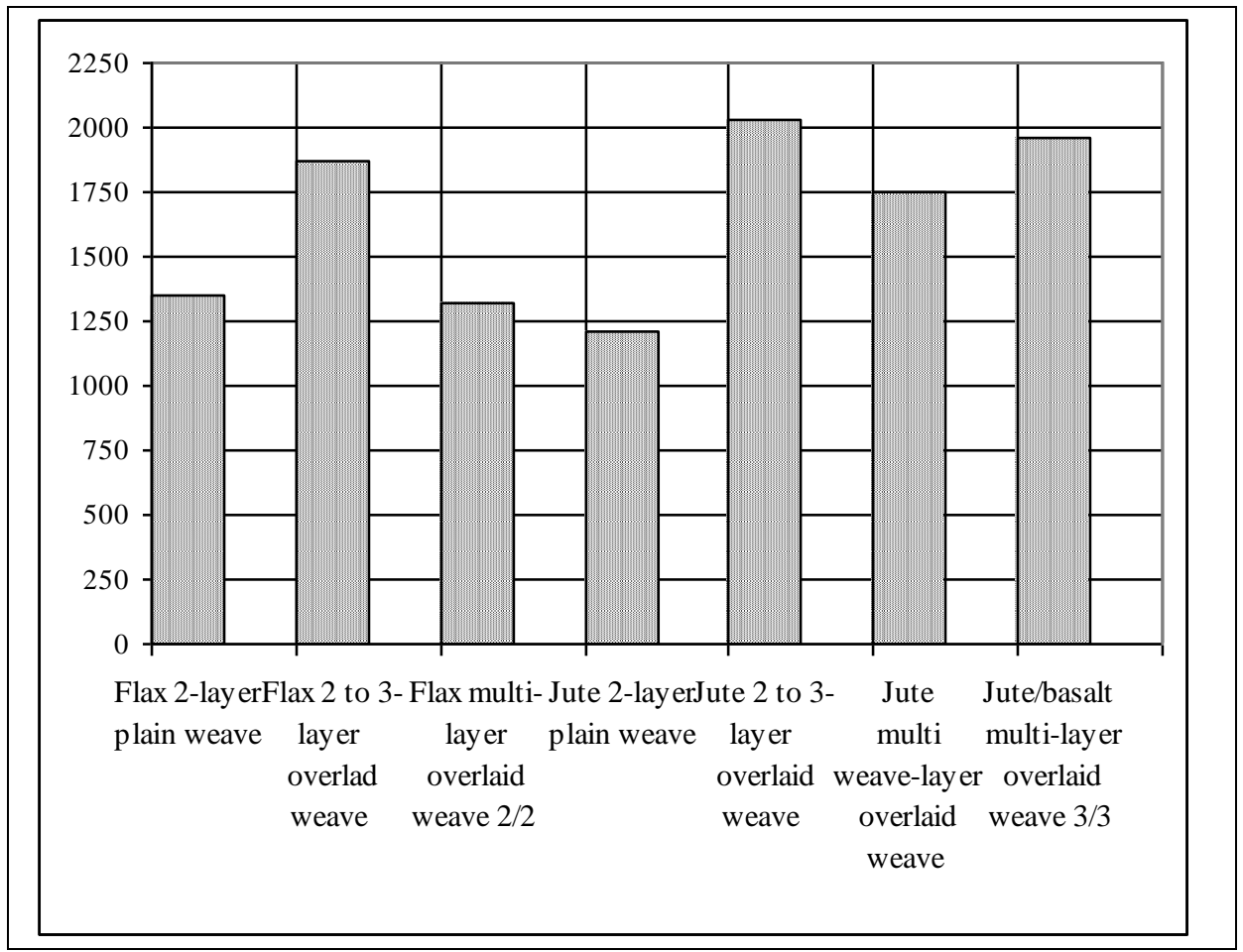

Fig. 4. Surface density of woven samples 


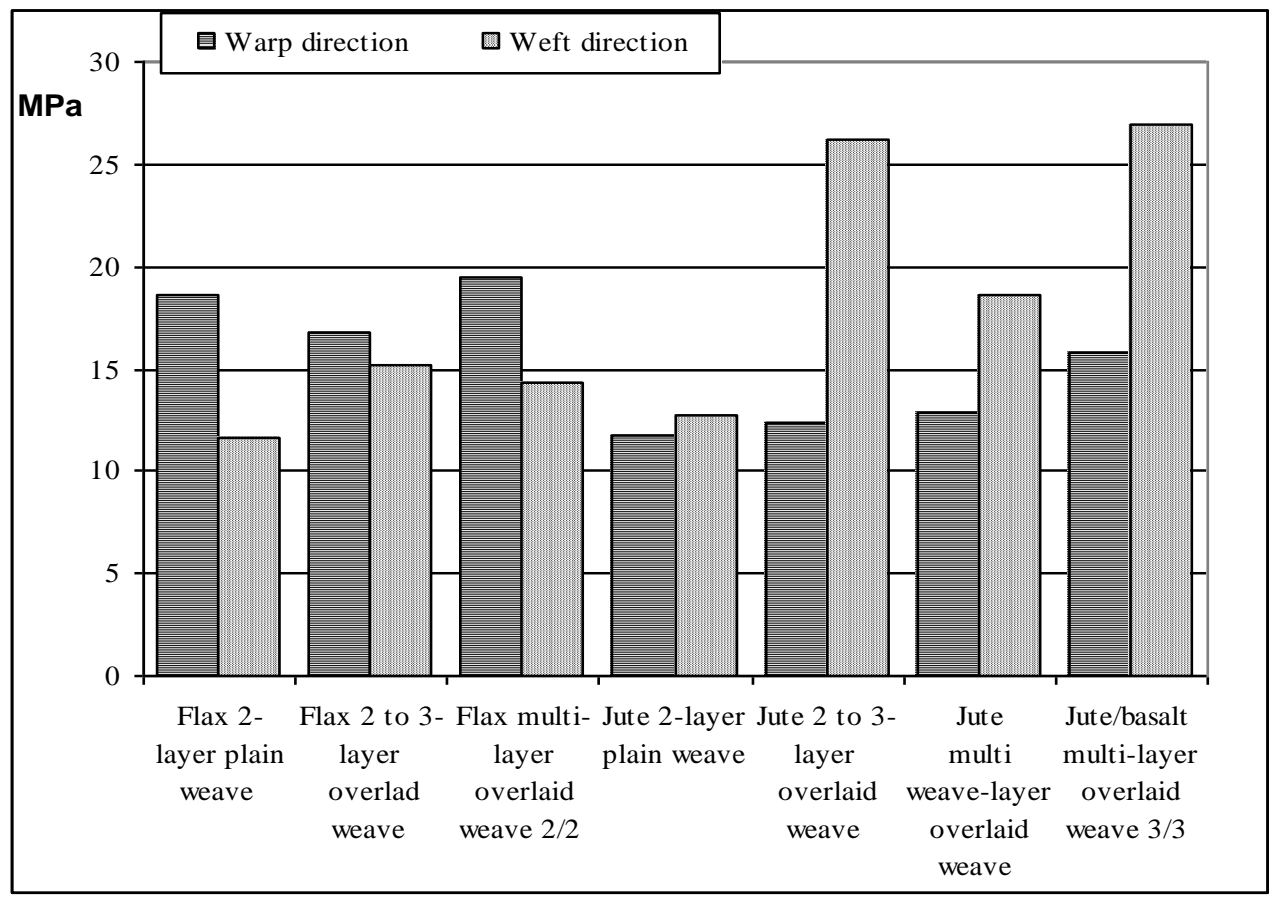

Fig. 5. Tensile stress of woven samples (Mpa) in worp and weft direction

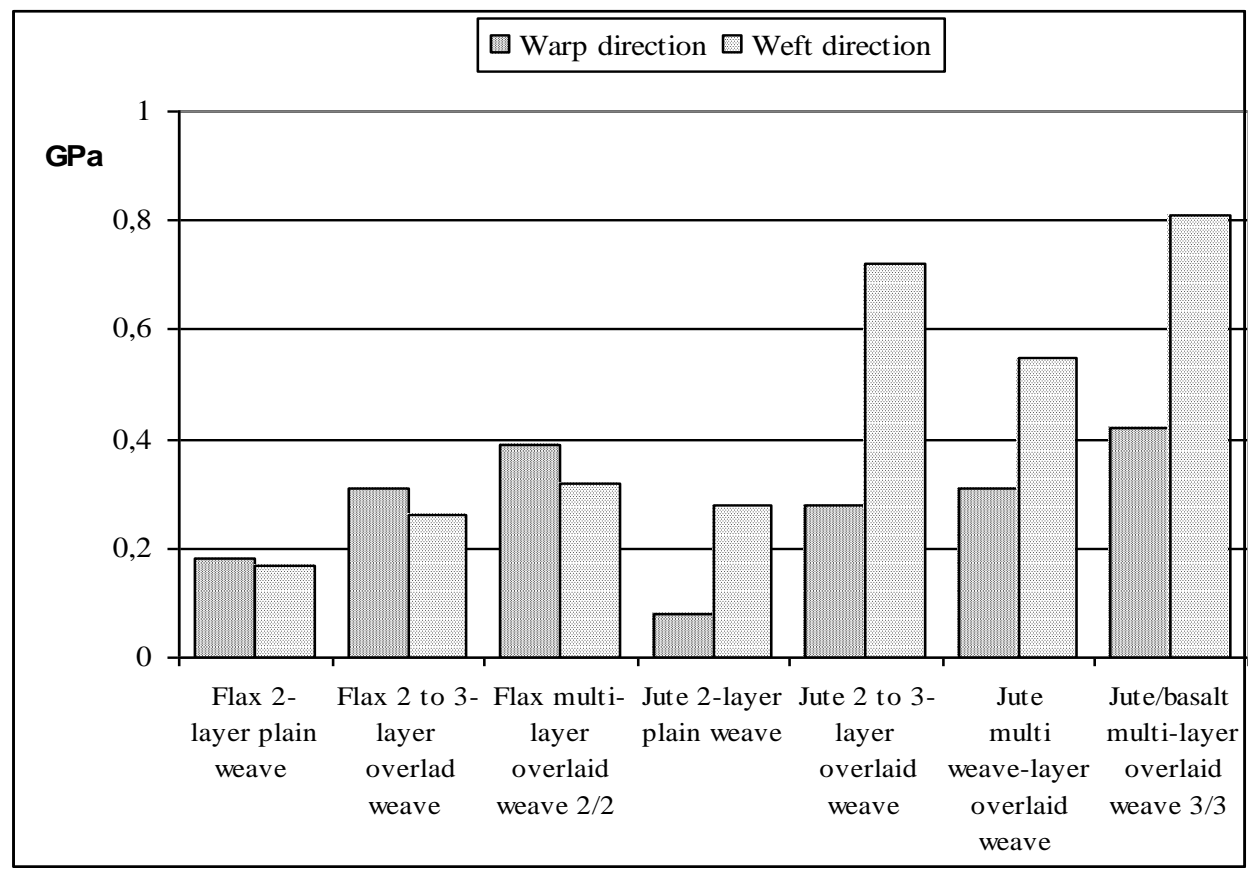

Fig. 6. Samples Young's modules in warp and weft direction

From Table 3 and graphs in Fig. 5 and Fig. 6 are seen that the largest values of tensile stress and modules show samples with a jute/basalt multi-layer overlaid weave $3 / 3$ tested in the weft direction (26,92 $\mathrm{MPa}$ and 0,81 GPa respetively), tensile stress for the same samples in warp direction is 1,7 times lower, module 1,93 times lower. Only a little lower values $(26,19$ Mpa) show samples from jute threads with 2 to 3-layer overlaid weave in weft direction that is 2,12 times more then in warp direction, module in weft direction exceed module in warp direction 2,57 times. For all three flax fabric samples tensile stress values in warp direction are slightly higher than in weft direction.

Development of integrated FRP composition is possible if textile components has alongation close to that parameter of matrix. Too large elongation of reinforcing construction leads to situation in which only matrix some time overtake load, as a result composite mechanical 
properties is like corresponging matrix properties and such defects of composite structure as cracks arose. From graph in Fig. 7 obvious very high extension in warp direction of two layer plain weave sample from jute threads (close to $16 \%$ ) and high tensile extension of flax 2layer plain weave. Reasonable seems last three structures with extension $4 \%$ or less in both directions

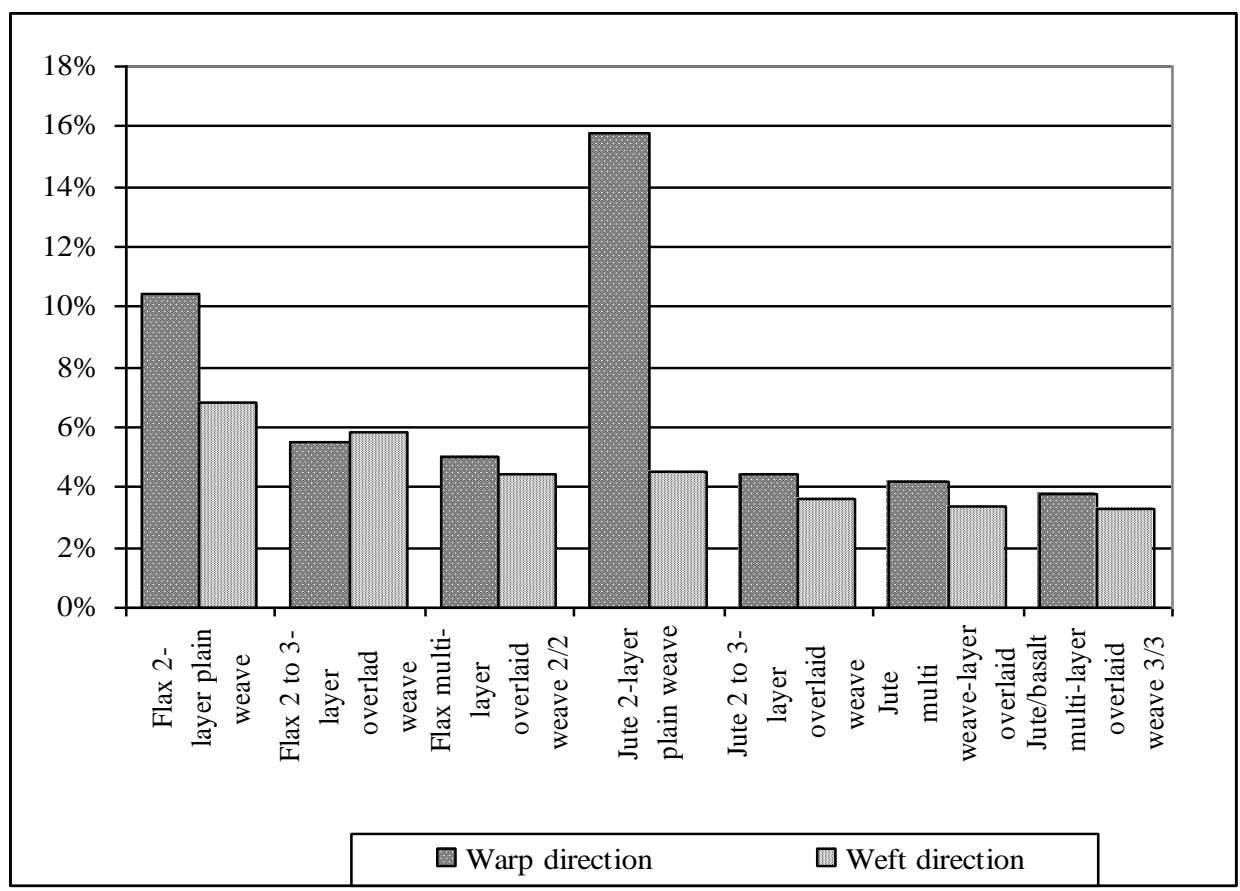

Fig. 7. Samples tensile extension in warp and weft direction

\section{Summary}

The technical textiles based composites are the rapidly developing light-weight engineering materials. The fabrics used in composites manufacture have to be especially engineered as a single-fabric system could impart reliability and performance of composite material.

Investigation of seven types of woven fabric structures from natural flax and jute threads interwoven with three different types of weaves show strong impact on fabrics investigated mechanical properties - tensile strength, extension and Young's module. Incorporation of basalt filament threads in weft system could substantially increase fabric mechanical properties in weft direction.

High tensile extension values in warp direction show 2-layer plain weave fabric samples, especially for fabric from jute threads.

\section{References}

1. D. Gopalakrishnan. New faces of tecnical textiles. Sardar Vallabhbhai Patel Institute of Textile Management, India, 2009.

2. 3-D textile reinforcements in composite materiāls, Woodhead publisching limited, Cambridge, Anglija, 2004

3. V. Lomov, D. Ivanov, I. Verpoest, A. E. Bogdanovich, D. Mungalov, M. Zako, T. Kurashiki, and H. Nakai, "Predictive Analyses and Experimental Validations of Effective Elastic Properties of 2D and 3D Woven Composites," Proceedings of ECCM-13, the 13th European Conference on Composite, Sweden, 2008.

4. S. V. Lomov, A. E. Bogdanovich, D. S. Ivanov, D. Mungalov, I. Verpoest, M. Karahan, "Damage Progression in 2D and Non-Crimp 3D Woven Composites," In: Proceedings of Composites 2009, 2nd ECCOMAS Thematic Conference on the Mechanical Response of Composites, Imperial College, London, 2009. 